\title{
ARTHROPOD PHOTOTAXIS AND ITS POSSIBLE EFFECT ON BIRD STRIKE RISK AT TWO NAMIBIAN AIRPORTS
}

\author{
HAUPTFLEISCH, M.L. ${ }^{1 *}-$ DALTON, C. ${ }^{1}$ \\ ${ }^{1}$ Department of Agriculture and Natural Resources Sciences, Polytechnic of Namibia \\ Private Bag 13388, Windhoek, Namibia \\ (phone: +264-81-124-1365; fax: +264-61-207-2141) \\ *Corresponding author \\ e-mail:mhauptfleisch@polytechnic.edu.na \\ (Received $9^{\text {th }}$ Dec 2014; accepted $20^{\text {th }}$ Feb 2015)
}

\begin{abstract}
Aircraft wildlife collisions are a global safety and financial problem for the aviation industry, with birds being the main concern. In Namibia, $97 \%$ of collisions at Namibia's two main airports are reported to be with insectivorous birds. Phototaxis was identified as a major attractant to insectivorous birds, which feed on the arthropods attracted to airport apron and terminal lights. This study considered the effect of light as an attraction at the rurally situated Hosea Kutako International and urban Eros airports. It further investigated the attractiveness of light colour (or wavelength) on arthropod abundance, biomass and diversity. The study found that phototaxis was a significant factor at Hosea Kutako only, and that white light was the main attractant for arthropods, specifically for large moths (Order Lepidoptera), while yellow and orange light attracted significantly less arthropods. The study indicates a high likelihood that the Hosea Kutako apron lights (white) are an important attractant for arthropods, and therefore indirectly insectivorous birds, which can be reduced by replacing them with orange or yellow filters.
\end{abstract}

Keywords: airport, arthropods, bird strike, phototaxis

\section{Introduction}

Aircraft-wildlife collisions (AWCs) are a global concern. Thorpe (2003) reported 42 fatal accidents, 231 human deaths and 80 destroyed aircraft in the world's aviation sector as a result of AWCs between 1912 and 2002, while Dolbeer et al. (2012) cited 229 human deaths and 210 destroyed aircraft since 1988 alone. At Namibia's two major airports, Hosea Kutako International and Eros (domestic), 128 AWC incidents were recorded between 2006 and 2010 (Hauptfleisch et al., 2013). Only two serious incidents were recorded in Namibia in the last five years. Damage from these incidents amounted to damages of over US\$ 2.5 million (Hauptfleisch and Avanant, 2012). The number of bird collisions in Namibia seems to fluctuate from between one or two collisions to 25 collisions per year per airport (Hauptfleisch et al., 2013). This is probably not a true version of the number of collisions, as reports on these incidents are not always filed, especially when there is little or no damage to the aircraft (Hauptfleisch et al., 2013).

Airports are described as complex habitats (Soldatini et al., 2010) and provide niches and ecosystem services such as primary food supply (grass / vegetation, insects, small mammals and carrion), water, shelter and nesting sites. Studying ecosystem components that provide these services should consequently be useful to airport wildlife management. At airports arthropods provide ecosystem services and food for birds and other wildlife (Bernhardt et al., 2010), were found to be attracted to the heat of runways and taxiways (Pennell, 2007), and use airport grasslands as refugia (Kutchbach-Brohl et al., 2010). Reductions in arthropod numbers at airports is expected to reduce risk of AWCs (Buckley and McCarthy, 1994; Bernhardt et al., 2010; Steele and Renner, 2010; 
Washburn et al., 2011) The possible influence of arthropods on bird strikes can therefore not be ignored.

Different methods to discourage birds from using airports, including killing them, have proved to have little effect on the numbers of birds (Froneman, 2000). It was however found that the management and manipulation of foraging opportunities to birds could be an effective strategy (Blackwell et al., 2013). Habitat management efforts, such as alteration of plant communities are an integral part of wildlife hazard management programs to reduce the risk of wildlife strikes at major airports globally (Washburn, 2011). Thus a more holistic approach which includes research into the ecosystem services provided to birds at the airports is useful.

During the period 2006 to 2010, fifteen bird species were responsible for bird strike incidents at Hosea Kutako and Eros Airports Namibia. Of those, 14 (92\%) all except White-backed Vulture (Gyps africanus), are described to rely on arthropods as a food source. The attractiveness of light to arthropods is widely known (Weiss et al., 1941; Van Tets et al., 1969; Ashfaq et al., 2005; Blanco and Hernández, 2006; Fox et al., 2006) and the effect of this phenomenon on attracting birds to the airports formed the motivation for this study. For safety and security reasons the International Civil Aviation Organisation (ICAO, 2004) requires that lights at airports be positioned in such a way that all aircraft on the apron are clearly visible at all times (ICAO 2004). Only white, yellow or orange light will suffice, as other colours like red and blue are too dark and are used for signalling (ICAO, 2004). According to Ashfaq et al. (2005) white light attracts more arthropods than yellow light, while red light, few or no arthropods. Arthropods are photosensitive and are thus either attracted to light (photo-positive) or repelled by it (photo-negative) (Shockley Cruz and Lindner, 2011), while natural environmental factors like humidity and temperature and surrounding land management may play a role in the behaviour of arthropods and thus influence their numbers at any given time (Jonas et al., 2002; Blanco and Hernandez, 2006). The attraction to light, however, can cause arthropods to become easy meals to birds as they become disorientated, collide into the light or congregate around it. Birds have been found to readily make use of these "artificial feeding stations" (Van Langevelde et al., 2011). Variations in intensity and spectral composition of artificial lighting have also been found to affect its attractiveness to arthropods (Van Langevelde et al. 2011). For example certain beetles (Order Coleoptera), crickets (Order Orthoptera), bees and desert ants (Order Hymenoptera) have been found to use the light polarisation patterns during dispersal and migration, while many nocturnal arthropods are attracted to artificial sources of polarised light (Horváth et al., 2009).

This study used field experiments to determine the extent to which light attracts insects, and also investigated whether light colour (wavelength) and surrounding land use plays a role in attractiveness to light to arthropods. It futher attempts to relate these results to the risk of aircraft-bird collision risk at the study airports.

\section{Materials and methods}

The study area is in the central highlands of Namibia's Khomas region. Three study sites were established: i) at Hosea Kutako International airport (Longitude: $17^{\circ} 28^{\prime} 0^{\prime \prime} \mathrm{E}$ and latitude $22^{\circ} 28^{\prime} 59^{\prime \prime} \mathrm{S}$ ), $40 \mathrm{~km}$ east of Windhoek, ii) a neighbouring game and cattle farm (Longitude: $17^{\circ} 29^{\prime} 09^{\prime \prime} \mathrm{E}$ and latitude $22^{\circ} 28^{\prime} 13^{\prime \prime} \mathrm{S}$ Oupembamewa, and iii) Eros 
Airport (longitude $17^{\circ} 4^{\prime} 59^{\prime \prime} \mathrm{E}$ and latitude $22^{\circ} 37^{\prime} 0^{\prime \prime} \mathrm{S}$ ) within the suburbs of Windhoek, Namibia's capital city.

Light traps were located at the three study sites for 6 consecutive nights (during April 2013). Each light trap consisted of a clear plastic tray as well as a light source. Controls consisted of the same without a light source. Mono-ethylene glycol was used to kill and preserve arthropods that fell into the light traps.

The light traps were set up in a grid pattern with random treatments (white, yellow, orange or no light), 50 metres apart. Light Emitting Diodes (LED lights) were used as it does not produce heat, a factor which can influence the attraction of arthropods (Fox et al., 2006). The lights were switched on at dusk and switched off at dawn the following morning.

Arthropods collected from each trap were identified, dried for 48 hours at $50^{\circ} \mathrm{C}$ and weighed. Individuals were identified to Order level to determine order richness and diversity using the Shannon Information Index (Manly, 2001) As the Order Lepidoptera were most abundant and a major prey component of insectivorous birds (Van Langevelde et al., 2011; Washburn et al., 2011), the assistance and expertise of the National Museum was called upon to identify Order Lepidoptera to Family level. A species of the order Hymenoptera (Anaplolepis custodiens - Pugnacious ant) which is diurnal (Picker, et al., 2004), were trapped in abundance in the control (especially at Eros airport). It was clear that this species was not attracted to light (being diurnal) and was probably attracted to the moisture in the light traps (personal observation, 13 April 2013). Hymenoptera was subsequently removed from further analysis. Trap success was calculated as the mean number of individuals trapped per night over 6 nights. Biomass was calculated as dry mass per order per light trap.

Normality of data was determined with the Shapiro-Wilk's W test. As the data was not normally distributed, a standard nonparametric test (Kruskal - Wallis for multiple analysis of variance), was used to compare land use and light colour. All data were statistically analysed by using Statistica ${ }^{\circledR}$ for Windows version 10 (StatSoft Inc., 2011). A statistically significant level of $95 \%(\mathrm{p}<0.05)$, was observed for all tests.

\section{Results}

A total of 3878 arthropods were trapped. 2760 (71.17\%) were collected at the farm (Oupembamewa), 283 (7.29\%) were collected at Eros Airport and 835 (21.53\%) were collected at Hosea Kutako (Table 1). Significantly higher trap success and order richness $(\mathrm{H}=36.44, \mathrm{p}<0.01)$ were found at the farm compared to Eros and Hosea Kutako Airports.

When combining the three study sites a total of $2066(53.27 \%)$ arthropods were trapped in light traps with white light, 737 (19\%) were trapped in light traps with orange light, 957 (24.67\%) were trapped in light traps with yellow light and 118 (3.04\%) were trapped in the control. Significantly higher arthropod numbers were found in traps bearing white light $(\mathrm{H}=30.39, \mathrm{p}<0.01)$ when compared to the control traps and traps fitted with yellow and orange lights.

Overall, white light showed a significantly higher trap success $(\mathrm{H}=51.63, \mathrm{p}<0.05)$ than orange light $(\mathrm{H}=46.79, \mathrm{p}<0.05)$, yellow light $(\mathrm{H}=44.15, \mathrm{p}<0.05)$ and the control $(\mathrm{H}=5.24, \mathrm{p}<0.05)($ Fig. 1a) (Table 1). Although less arthropods were caught at orange light traps than yellow, this difference was not significant. Significantly less arthropods were captured at the control compared to all light colours. 
Table 1. Abundance (number of individuals trapped), biomass, order richness and diversity of arthropods at light traps in three land use areas $(W=$ white light, $O=$ orange light, $Y=$ yellow light, $C=$ control / no light).

\begin{tabular}{|c|c|c|c|c|c|c|c|c|c|c|c|c|}
\hline \multirow[b]{2}{*}{ Orders } & \multicolumn{4}{|c|}{ Hosea Kutako Airport } & \multicolumn{4}{|c|}{ Eros Airport } & \multicolumn{4}{|c|}{ Oupembamewa Farm } \\
\hline & $\mathrm{W}$ & $\mathrm{O}$ & $\mathrm{Y}$ & $\mathrm{C}$ & $\mathrm{W}$ & $\mathrm{O}$ & $\mathrm{Y}$ & $\mathrm{C}$ & W & $\mathrm{O}$ & $\mathrm{Y}$ & $\mathrm{C}$ \\
\hline \multicolumn{13}{|l|}{$\begin{array}{l}\text { Class- } \\
\text { Arachnida }\end{array}$} \\
\hline Araneae & 40 & 22 & 30 & 3 & 14 & 5 & 14 & 2 & 96 & 109 & 92 & 1 \\
\hline Acari & 3 & 5 & 4 & 1 & 1 & 0 & 0 & 0 & 1 & 0 & 1 & 0 \\
\hline Amblypygi & 0 & 1 & 2 & 0 & 0 & 0 & 0 & 0 & 0 & 0 & 0 & 0 \\
\hline Solpugida & 1 & 0 & 0 & 0 & 0 & 0 & 0 & 0 & 0 & 0 & 1 & 0 \\
\hline Class- & & & & & & & & & & & & \\
\hline Entognatha & & & & & & & & & & & & \\
\hline Collembola & 30 & 40 & 13 & 1 & 9 & 3 & 8 & 0 & 16 & 16 & 25 & 4 \\
\hline Class-Insecta & & & & & & & & & & & & \\
\hline Lepidoptera & 156 & 22 & 18 & 1 & 30 & 6 & 7 & 1 & 856 & 140 & 268 & 2 \\
\hline Hemiptera & 124 & 41 & 29 & 9 & 59 & 2 & 14 & 10 & 177 & 115 & 123 & 6 \\
\hline Orthoptera & 6 & 4 & 5 & 3 & 6 & 2 & 2 & 5 & 10 & 8 & 10 & 5 \\
\hline Coleoptera & 32 & 17 & 16 & 2 & 4 & 4 & 3 & 8 & 34 & 30 & 29 & 1 \\
\hline Diptera & 77 & 11 & 10 & 8 & 27 & 5 & 10 & 4 & 178 & 87 & 72 & 9 \\
\hline Phasmatodea & 0 & 0 & 0 & 0 & 0 & 0 & 0 & 0 & 0 & 1 & 0 & 0 \\
\hline Blattodea & 4 & 7 & 4 & 2 & 7 & 1 & 2 & 2 & 0 & 1 & 0 & 0 \\
\hline Isoptera & 0 & 0 & 0 & 0 & 0 & 1 & 1 & 0 & 0 & 1 & 1 & 0 \\
\hline Mantodea & 2 & 0 & 0 & 0 & 3 & 0 & 1 & 0 & 53 & 22 & 43 & 0 \\
\hline Plecoptera & 0 & 0 & 0 & 0 & 0 & 0 & 0 & 0 & 0 & 0 & 1 & 0 \\
\hline Thysanoptera & 1 & 2 & 6 & 16 & 0 & 0 & 0 & 0 & 0 & 4 & 4 & 5 \\
\hline Psocoptera & 3 & 0 & 0 & 0 & 0 & 0 & 0 & 0 & 5 & 2 & 3 & 1 \\
\hline Neuroptera & 1 & 0 & 0 & 0 & 0 & 0 & 0 & 0 & 0 & 0 & 0 & 0 \\
\hline Total $n$ & 480 & 172 & 127 & 46 & 160 & 29 & 62 & 32 & 1426 & 536 & 673 & 34 \\
\hline $\begin{array}{l}\text { Order } \\
\text { richness }\end{array}$ & 14 & 11 & 10 & 10 & 10 & 9 & 10 & 7 & 10 & 13 & 14 & 9 \\
\hline $\begin{array}{l}\text { Shannon } \\
\text { diversity } \\
\text { (Orders) }\end{array}$ & 1.77 & 1.93 & 1.86 & 1.92 & 1.74 & 1.19 & 1.94 & 1.39 & 1.2 & 1.73 & 1.74 & 1.92 \\
\hline Biomass (g) & 21.95 & 32.34 & 35.18 & 4.55 & 17.45 & 11.1 & 8.54 & 4.1 & 6.92 & 13.02 & 9.03 & 4.13 \\
\hline
\end{tabular}

Although the difference between white light and other light traps was significant at all three study sites, Hosea Kutako (Fig. 1b) and the farm (Fig. 1d) site showed a greater difference than at Eros (Fig. 1c) (Table 1).

Arthropod biomass was highest at Hosea Kutako and lowest at the farm. Total arthropod biomass at Hosea Kutako was $94.02 \mathrm{~g}$ (49.09\%), at Eros $56.27 \mathrm{~g}$ (29.38\%) and Farm Oupembamewa $41.23 \mathrm{~g}(21.52 \%)$. Overall order richness was highest at the farm Oupembamewa, followed by Hosea Kutako and Eros Airports. Per light colour order richness was highest at the rural study sites, Hosea Kutako (14) and Oupembamewa (14), order richness was highest at the farm for yellow light and at Hosea Kutako for white light. Overall order diversity was highest at Eros for yellow light (Shannon 1.94) as well as lowest at Eros for orange light (Shannon 1.19). Highest order diversity at Hosea Kutako was found at orange light (Shannon 1.93) and lowest at white light (Shannon 1.77)traps, while at Oupembamewa order diversity was highest at the control (Shannon 1.92) and lowest at white light (Shannon 1.2) (Table 1).

Individuals of the order Lepidoptera were most abundant at $1507(38,86 \%)$ individuals (Fig. 2), of the families Lymantriidae, Limacodidae, Noctuidae and Geometridae. Hemiptera were second most abundant at 709 (18.28\%) individuals, followed by orders Diptera, Araneae, Coleoptera, Collembola, Mantodea and 
Orthoptera. Significantly greater abundance of Lepidoptera was attracted to white light than to any either orange or yellow light. $(\mathrm{H}=85.32$, $\mathrm{p}<0.01)$ (Fig. 2).
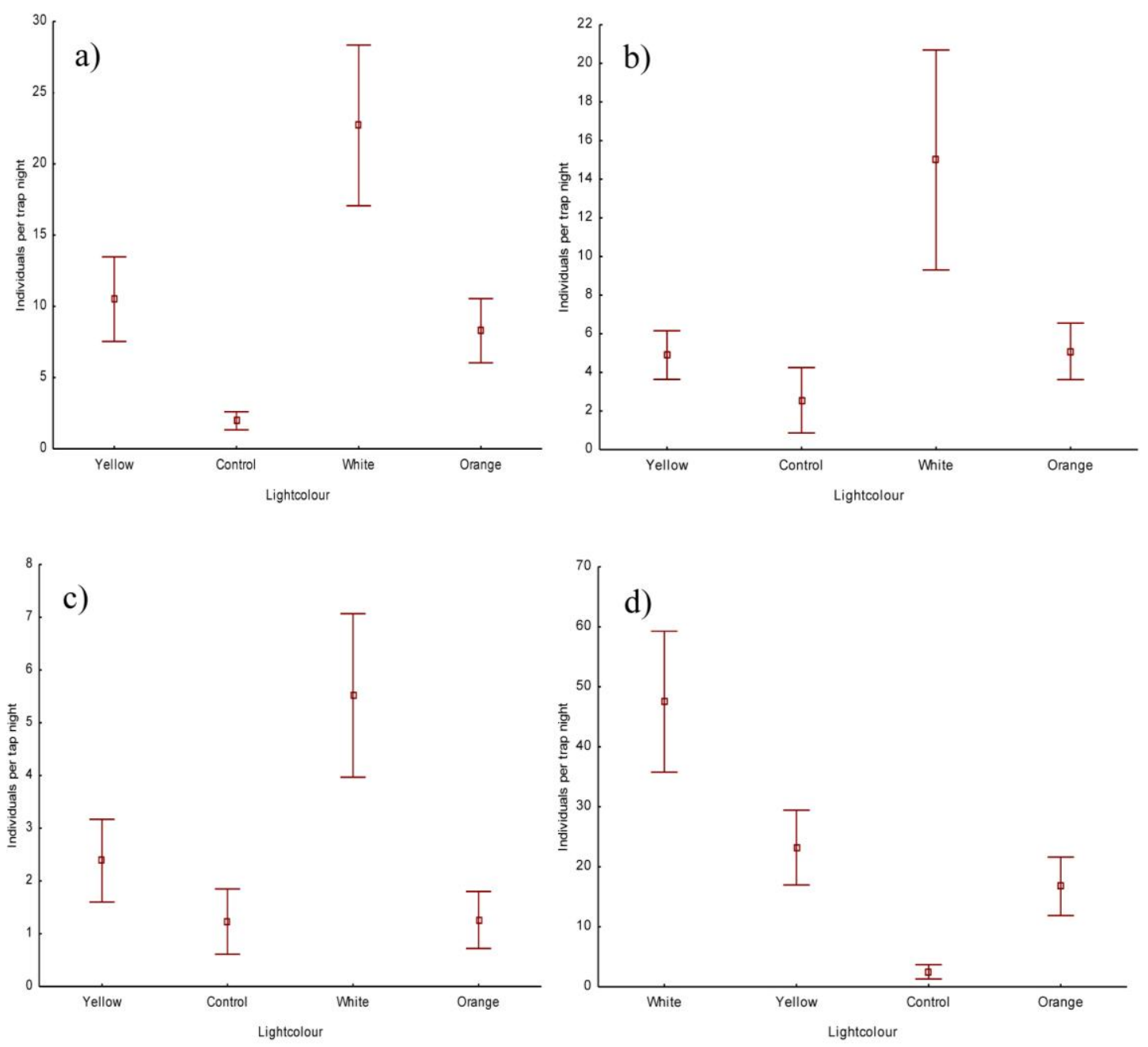

Figure 1. Trap success per light colour at a) All light traps, b) Hosea Kutako Airport, c) Eros Airport, and d) Farm site (mean, whiskers $=95 \%$ confidence interval).

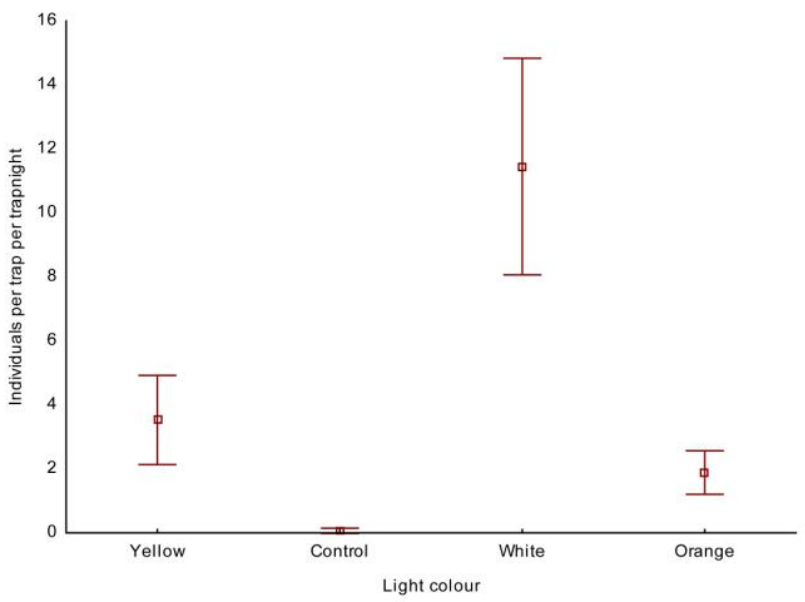

Figure 2. Trap success of Order Lepidoptera per light colour.

APPLIED ECOLOGY AND ENVIRONMENTAL RESEARCH 13(4): 957-965.

http://www.aloki.hu • ISSN 15891623 (Print) • ISSN 17850037 (Online)

DOI: 10.15666/aeer/1304_957965

(C) 2015, ALÖKI Kft., Budapest, Hungary 


\section{Discussion}

This study confirmed other findings (Weiss, 1946; Prokopy and Owens, 1983; Frank, 1988; Stavenga, 2002; Ashfaq et al., 2005; Cloyd et al., 2007; Fox et al., 2007; Buschke and Seaman, 2011; Shockley Cruz and Lindner, 2011; van Langevelde, 2011) that white light is a major attractant to arthropods. When considering land use, the effect of light as attractant was reduced by increased ambient light sources. Being in an urban setting, Eros Airport is surrounded by artificial light sources, while Hosea Kutako Airport is surrounded by farming and conservation areas with minimal artificial light. The results indicate a clear increase in attractiveness of all (particularly white) light sources to arthropods with decreased surrounding light sources, making it a significant factor at airports situated rurally (e.g. many parts of Africa) (Hauptfleisch, 2014). This factor is already in use to reduce the nuisance of nocturnal insects in the tourism (Roqoe Albello et al., 2007) and other industries (Chartered Institute of Environmental Health, 2009), while only one other study (Frank, 1988) of this phenomenon at an airport could be found.

Birds most commonly involved in collisions with aircraft at Hosea Kutako Airport are Crowned Lapwing (Vanellus coronatus) (16\%) and Helmeted Guineafowl (Numida meleagris) (9\%) (Hauptfleisch et al., 2013), both insectivorous (Hockey et al., 2005). Crowned Lapwing (Vanellus coronatus) were responsible for two thirds of collisions at Eros Airport (Hauptfleisch et al., 2013). Stomach and crop content analyses at the two study airports during 2010-2012 revealed arthropods as a major food source (Hauptfleisch, 2011).

Of the family Geometridae, moths with larger body mass, larger wing dimensions and larger eyes have been found to be attracted to light dominated by smaller wavelengths (white spectrum) (Van Langevelde et al., 2011) a finding confirmed by this study. According to Prokopy and Owens (2011) and Qiu and Arikawa (2011) possible reason for this is that moths have compound eyes which are sensitive to wavelengths ranging from UV-light to red light. Moths are an important part of many birds' diet (Van Langevelde et al., 2011; Washburn et al., 2011) with adult birds found to feed their young large moth species of the families Cossidae, Sphingidae, Noctuidae and Geometrida (Van Langevelde et al., 2011) as a result of their relative lack of exoskeletal and mandibular protection.

The presence of predatory arthropods, of the orders Hemiptera (family, Reduviidae and Nepidae), Mantodea (family Hymenopdidae, Mantidae and Empusidae), Coleoptera (family Carabidae and Dytiscidae) (Table 1), indicates that not all arthropods were attracted to the light source. Predators were likely attracted to the abundance of photophilic insects, as found with other studies (Bruce-White and Shardlow, 2011; Davies et al., 2012.; Meyer, 2012; Wang et al., 2014).

Biomass was found not to be a reliable measure of attractiveness as a result of the substantial variance in the dry mass of different arthropod species. For example, arthropods from the Order Coleoptera, family Scarabaeidae, were caught in some of the light traps, varying in size from 6-50 mm (Scholtz and Holm, 1996) with a mass of up to $88 \mathrm{~g}$ while individuals of the order Lepidoptera would weigh very little after drying, even though individuals vary in wingspan size from 3mm-180mm (Scholtz and Holm, 1996).

The study suggests that arthropod abundance at Hosea Kutako airport is an important factor which can be reduced by filtering the airport apron lights (white) with yellow or orange filters, provided the primary security function of the lights are not compromised. This factor is however not significant at the urban Eros airport. An up-scaled study is underway to determine arthropod abundance at the apron lights themselves. 
Acknowledgements. The Namibia Airports Company, and the Trumper family are thanked for providing their properties as study areas. The National Museum of Namibia is thanked for providing access to their study collections for identification of arthropod families.

\section{REFERENCES}

[1] Ashfaq, M., Khan, R.A., Khan, M.A., Rasheed, F., Hafeez, S. (2005): Insect orientation to various color (sic) lights in the agricultural biomes of Faisalabad. - Pakistan Entomologist 27: 49-52.

[2] Bernhardt, G.E., Kutschbach - Brohl, L., Washburn, B.E., Chapman, R., Francoeur, L. (2010): Temporal variation in terrestrial invertebrate consumption by Laughing Gulls in New York. http.//digital commons.unl.edu/icwdm_usdanwre/861.

[3] Blackwell, B.F., Seamans, T.W., Schmidt, P.M., Devault, T.L., Belant, J.L. (2013): A framework for managing airport grasslands and birds amidst conflicting priorities. - Ibis 155: 189-193.

[4] Blanco, C.A., Hernandez, G. (2006): Prediction of masked chafer, Cyclocephala pasadenae, capture in light traps using a degree - day model. - Journal of Insect Science 6: $1-6$.

[5] Bruce-White, C., Shardlow, M. (2011): A review of the impact of artificial light on invertebrates. (2011th ed.). Buglife - The Invertabrate Conservation Trust. http://www.kentbutterflies.org/kentmoths/downloads/pdfs/others/Buglifereport.pdf.

[6] Buckley, P.A., McCarthy, M.A. (1994): Insects, vegetation, and the control of laughing gulls (Larus atricilla) at Kennedy International Airport, New York City. - Journal of Applied Ecology 31: 291-302.

[7] Buschke, F.T., Seaman, M.T. (2011): Functional feeding groups as a taxonomic surrogate for a grassland arthropod assemblage. - African Invertebrates 52: 217-228.

[8] Chartered Institute of Environmental Health (2009): Pest control procedures in the food industry,London.

http://www.cieh.org/uploadedfiles/core/policy/publications_and_information_services/po licy_publications/publications/pest_control_food_industry.pdf.

[9] Cloyd, R.A., Dickinson, A., Larson, R.A., Marley, K.A. (2007): Phototaxis of fungus gnat, Bradysia sp. nr coprophila (Lintner) (Diptera: Sciaridae), adults to different light intensities. - HortScience 42(5): 1217-1220.

[10] Davies, T.W., Bennie, J., Gaston, K.J. (2012): Street lighting changes the composition of invertebrate communities. Biological Letters. doi:10.1098/rsbl.2012.0216.

[11] Dolbeer, R.A., Eschenfelder, P. (2002): Population increases of large bird species in relation to impact standards for aircraft engines and airframes. FAA Bird strike committee presentation. http://www.airporttech.tc.faa.gov/naptf/.

[12] Dolbeer, R.A., Begier, M.J. (2012): Comparison of wildlife strike data among airports to improve aviation safety. IBSC30. IBSC/WBA conference, Stavanger. pp 25-29.

[13] Fox, G.L., Coyle-Thompson, A., Bellinger, P.F., Cohen, W. (2006): Phototactic responses to ultraviolet and white light in various species of Collembola, including the eyeless species, Folsomia candida. - Journal of Insect Science 7: 1-12.

[14] Frank, K.D. (1988): Impact of outdoor lighting on moths: an assessment. - Jounral of the Lepidopterists' Society 42: 63-93.

[15] Froneman, A. (2000): Towards the management of bird hazards on South African airports. - Proceedings of the International Bird Strike Committee IBSC25/WP-SA5, Amsterdam, Netherlands.

[16] Hauptfleisch, M.L. (2009): Impact Assessment to solve aircraft-wildlife collisions. Proceedings of the 2009 IAIA conference: Impact Assessment and human wellbeing. Accra, Ghana. 
[17] Hauptfleisch, M.L., Avenant, N.L. (2012): Human - Wildlife conflict takes flight; ecological scrutiny of aircraft - wildlife collisions in Namibia. Southern African Wildlife Management Association Conference. Bloemfontein, South Africa. www.sawma.co.za/images/Human_wildlife_conflict_takes_flight_Morgan_Hauptfleisch. pdf.

[18] Hauptfleisch, M.L. (2012): Report on bird strike at Eros and Hosea Kutako Airports. WARN newsletter 2(4): 1.

[19] Hauptfleisch, M.L., Avenant, N.L., Tsowaseb, A. (2013): Aircraft-wildlife collisions at two major Namibian airports from 2006-2010. - South African Journal of Wildlife Research 43: 177-184.

[20] Hauptfleisch, M.L. (2014): The use of ecosystem parameters in predicting the risk of aircraft-wildlife collisions at Namibian airports. PhD Thesis. University of the Free State. Bloemfontein, South Africa.

[21] Hockey, P. A. R., Dean, W. R. J., Ryan, P.G. (eds.) (2005): Roberts-Birds of Southern Africa, VII Edition. - John Voelcker Bird Book Fund, Cape Town, South Africa.

[22] Horváth, G., Kriska, G., Malik, P., Robertson, B. (2009): Polarized light pollution:a new kind of ecological photopollution. - Frontiers in Ecology and the Environment 7: 317325.

[23] ICAO (2004): Airodrome (sic) design manual. Part 4 Visual Aids. International Civil Aviation Organisation.

[24] Jonas, J.L., Whiles, M.R., Charlton, R.E. (2002): Above ground invertebrate response to lane management difference in a central Kansas grassland. - Environmental Entomology 31(6): 1142-1152.

[25] Kutschbach-Brohl, L., Washburn, B.E., Bernard, G.E., Chipman, R.B., Francoeur, L.C. (2010): Arthropods of a semi- natural grassland in an urban environment: The John. F.Kennedy International Airport, New York. - Journal of Insect Conservation 14: 347358.

[26] Manly, B.F.J. (2001): Statistics for Environmental Science and Management. - Chapman $\&$ Hall, Florida.

[27] Mendelsohn J., Jarvis, A., Roberts, C., Robertson, T. (2002): Atlas of Namibia: A portrait of the land and its people. - David Philip, Cape Town, South Africa.

[28] Meyer, L.A. (2012): In Light of Energy: Influences of Light Pollution on Linked Stream Riparian Invertebrate Communities. The Ohio State University. https://etd.ohiolink.edu/!etd.send_file?accession=osu1345479410\&disposition=inline.

[29] Oduntan, O.O., Akinyemi, A.F., Abiodun, O.A. (2012): Assessment of bird strike occurrences and bird species abundance at the Murtala Muhammed International Airport, Lagos. - Journal of Agricultural Science and Soil Science 2: 223-227.

[30] Picker, M., Griffiths, C., Weaving, A. (2004): Field guide to insects of South Africa. Struik, Cape Town, South Africa.

[31] Pennell, C. G. L., Rolston, M. P. (2007): The development of natural fungus in grass for wildlife management in the aviation industry. Australian Airports Association. 24th National Convention, Hobart, Australia.

[32] Prokopy, R.J., Owens, E.D. (1983): Visual detection of plants by herbivorous insects. Annual Review of Entomology 28: 337-364.

[33] Qiu, X., Arikawa, K. (2003): Polymorphism of red receptors: sensitivity spectra of proximal photoreceptors in the small white butterfly Pieris rapae crucivora. - Journal of Experimental Biology 206: 2787-2793.

[34] Roqoe Albello, L., Chauca, E.L., Gaona, O.C. (2007): Dispersal of insect species attracted to ship lights: Conservation implications for Galapagos. Charles Darwin Foundation. http://www.galapagos.org/wp-content/uploads/2012/04/biodiv3-insectspecies-dispersal.pdf.

[35] Scholtz, C.H., Holm, E. (1985): Insects of Southern Africa. - University of Pretoria. Pretoria, South Africa. 
[36] Shockley Cruz, M., Lindner, R. (2011): Insect vision: ultraviolet, colour, and LED light. www.cree.xom-media/files/cree/lighting/misc520Tech\%20docs/insect vision_UVcolorandLEDlight.pdf.

[37] Short, J.J., Kelley, M.E., Speelman, R.J., McCarty, R.E. (2000): Bird strike prevention: Applying aero- science and bio- science. - Proceedings of the International Bird Strike Committee, Amsterdam, The Netherlands.

[38] Sinclair. I., Ryan. P. (2009): Volledige fotografiese veldgids van Suider Afrika: Voëls. Struik Nature, Cape Town, South Africa.

[39] Statistica ${ }^{\circledR}$ for Windows version 10. StatSoft Inc. (2011).

[40] Stavenga, D. (2002): Colour in the eyes of insects. - Journal of Comparitive Physiology A 188: 337-348.

[41] Soldatini,C., Georgalas, V., Torricelli, P., Albores-Barajas, Y.V. (2010): An ecological approach to bird strike risk analysis. - European Journal of Wildlife Research 56: 623632.

[42] Steele, W.K., Renner, S. (2010): Reducing the incidence of bird strikes involving high risk species at Melbourne airport, Australia. - Proceedings of the 29th meeting of the International Bird Strike Committee. Cairns, Australia.

[43] Thorpe, J. (2003): Fatalities and destroyed civil aircraft due to bird strikes, 1912-2002. International Bird Strike Committee Publication, IBSC26/WP-SA 1, Warsaw, Poland.

[44] Van Langeveldt, F., Ettema, J.A., Donners, M., WallisdeVries, M.F., Groenendijk, D. (2011): Effect of spectral composition of artificial light on the attraction of moths. Biology and Conservation 144: 2274-2281.

[45] Van Tets, G.F., Vestjens, W.J.M., Slater, E. (1969): Orange runway lighting as a method for reducing bird strike damage to aircraft. - CSIRO Wildlife Research 14: 129-51.

[46] Washburn, B.E., Bernhardt, G.E., Kutschbach-Brohl, L.A. (2011): Using dietary analysis to reduce the risk of wildlife aircraft collisions. - Human Wildlife Conflicts 5(2): 204209.

[47] Weiss, H.B., Soraci, F.A., McCoy Jr, E.E. (1941) Additional notes on the behaviour of certain insects to different wave-lenghts of light. - Journal of the New York Entomological Society 49: 148-159.

[48] Wang, S., Wang,K., Michaud, J.P., Zhang, F. Tan, X. (2014) Reproductive performance of Propylea japonica (Coleoptera: Coccinellidae) under various light intensities, wavelengths and photoperiods. - European Journal of Entomology 111: 341-347. 